\title{
Research Theme Identification by Japanese Education Department Lecturers
}

\author{
Amira Agustin Kocimaheni \\ Universitas Negeri Surabaya \\ Surabaya, Indonesia \\ amiraagustin@unesa.ac.id
}

\author{
Djodjok Soepardjo \\ Universitas Negeri Surabaya \\ Surabaya, Indonesia \\ djodjosoepardjo@unesa.ac.id
}

\author{
Rusmiyati \\ Universitas Negeri Surabaya \\ Surabaya, Indonesia \\ rusmiyati@unesa.ac.id
}

\begin{abstract}
The aim of this research is to investigate the research theme and focus that have been conducted by lecturers, and the theme development of the future research. It is a descriptive research using purposive sampling methods. The sampling is in the form of the research results or reports done by lecturers for the last five years from 2015 to 2019. This research uses check-list documentation and questionnaire as the research instruments. As for the results, it is shown that there were 28 research had been conducted during the years 2015 to 2019. Based on the research rank, theme, and focus, "Teaching Media" were the most-researched topic with 8 research in total. Meanwhile, for the future theme development will be about teaching phenomenon using Information and Communication Technologies (ICT)
\end{abstract}

Keywords-Japanese Education lecturers; identification; research theme; research focus

\section{INTRODUCTION}

As lecturers, it is one of the duties for them to conduct a research which has purposes to develop ones' knowledge and to support the academic activities. This statement is also in line with the University's Tridharma which states that it is compulsory for every university in Indonesia to access education, conduct research, and serve the community, as it is written in the Constitution of Republic of Indonesia No. 12 Year 2012, Article 1 Section 9 [1].

A good research is a research that discusses topics reflecting the problems in the society. By doing so, the results of research can be published through both journals and proceeding papers which purpose is to help people, especially in the teaching of Japanese language. There are various problems occur when it comes to teach Japanese language. Thus, it is needed for the researchers to conduct various related-studies to help proposing solutions and innovations towards those problems. Besides, a research also has an important role as an indicator for university's performance evaluation, for example, for accreditation purposes.

By analyzing the most-researched topics or focuses of research conducted by the lecturers, it will be easier to divide which research themes that had been done previously and which ones could be done in the future.

On the other hand, up to present time, there is not yet a particular identification related to the deployment and the tendency of certain research themes conducted by the lecturers, especially based on the research type, research focus, and research subject. By investigating the research themes, then, the future conduct would be deciding the themes development of the research in a particular Japanese Language and Literature in a university in Surabaya, specifically Japanese Education major which has been adjusted to research roadmap and Rencana Induk Penelitian (RIP) and Pengabdian kepada Masyarakat (LPPM) of a certain university in Surabaya, in the year of 2016 to 2020 [2].

The aims of this research is elaborated as follows; 1) to identify the research themes and focuses which have been done by the lecturers based on the potential research; and 2) to investigate the development of research themes of lecturers teaching Japanese Education major.

The positive implications of this study will be addressed to; 1) University and Faculty, in a form of research theme identification; 2) Japanese Education Department, by examining research type, research category, research field, and research theme done by lecturers to the development of the department; and 3) Lecturers of the Japanese Education Department, that it is hoped for this research to be reflected on their previous research for a greater result in the future. It is in correlation with the research theme development in the department that should be put as a priority.

University Tridharma is one of important matters that every university in Indonesia must take into account which is already written in the Constitution of Republic of Indonesia No. 12 Year 2012, Article 1 Section 9 [1]. It has three essential aspects, namely Education and Teaching, Research and Development, as well as Community Service. The focus of this research is specifically on the Research and Development which have a crucial role to the success of science and technology development. Therefore, in doing a research, it is 
necessary that every research has to be impactful to the surroundings both in the present time and in the future.

As stated by Gay (1981: 6) [3], research is the formal and systematic application of scientific method to the study of problems. In general, a research is associated with scrutinizing, experimenting, and developing which are based on the scientific approach done in formal and systematic ways to find solutions for the existing problems. This statement is in line with Sevilla (1993) [4] that a research refers to theory viewing, theory experimenting, or problem solving. Principally, problems occur in the society need an effort to be solved. To be able to propose better and exact solutions toward some issues, it is necessary to conduct a systematic research. Tuckman (1972: 1) [5] describes that research is a systematic attempt to provide answers to questions. The answer can be in a form of abstract and general, in other words, it is also known as a basic research. Also, the answer can be concrete and specific that is referred to an applied research. The stages of both kinds of research normally start with data collection and data formulation, then the research results can be concluded based on the data analysis.

The purpose of a research is to develop science. The growing of science does not only become an important role to the development of an institution, but also to the prosperity of a community. It also has a great contribution to the nation and country [6].

One particular state university in Surabaya has both education and non-education program. Based on RIP and LPPM of this institution in the year of 2016 to 2020 [2], in a wider mandate that this university has, it has been explained that the opening of non-education program that is related to science, technology, social, and culture, is meant to strengthen and support the education program so that the graduates will master a professional competence. It is also hoped that the research in the education field will have a more central role. Furthermore, the research in the field of non-education also immensely contributes to the balance of both programs.

Potential research that have been developed in one certain state university in Surabaya are divided into two large groups, namely 1) education, that covers a research focusing on the early education, primary education, secondary education, special education, non-formal education, counseling, psychology, as well as education technology; and 2) noneducation, that includes a research related to social sciences, humanities, and science technology.

Meanwhile, as for the research theme and focus, it is classified into education and non-education as follows.

\section{A. Research Theme and Focus in Education Field}

It includes curriculum, teaching materials and learning sources, teaching and learning strategies, learning model and approach, learning media, learning environment, education facilities, teacher's competence, learner's characteristics, education management and policy, evaluation and assessment, counseling, Character Building, Education Technology, Psychology Education, Online learning, as well as Blended or Hybrid learning.

\section{B. Research Theme and Focus in Non-Education Field}

It is classified into 1) poverty alleviation; 2) climate change and biodiversity; 3) new and renewable energy; 4) food safety and security; 5) health, tropical diseases, nutrition, and medicine; 6) disaster management; 7) nation integration and social harmony; 8) regional autonomy and decentralization; 9) arts and culture/creative industry; 10) infrastructure, transportation, and defense technology; 11) technology of information and communication; and 12) advanced and maritime materials.

Based on each categorization of both fields, it can be concluded that potential research of a particular state university in Surabaya that is suitable with the disciplines in Japanese Education major is the education field. Furthermore, the research themes and focuses in the education field elaborated above become a foundation for the classification of research results done by the lecturers in Japanese Education Department of related institution.

Research roadmap is the guidance and target of the research that becomes the purpose of the study the researcher wishes to achieve. Various research that previously had been done can clearly determine the professionalism of the researcher in the related field, and can provide the readers with the view of previous, on-going, and future studies. One research can be conducted for five to twenty years, both in ways of mono and multidiscipline. Roadmap is in a form of roadmap research development (R\&D) methods and/or product.

In one research roadmap, it contains three parts namely basic research (R\&D), applied research (technology), and product development research. To ease the comprehension towards roadmap, it can be displayed in a form of graphic (e.g. using $x$ as time and $y$ as event), fishbone diagram, or diagram.

Roadmap is quite different with research plot or research methods. The outcomes of roadmap can be in a form of Hak Kekayaan Intelektual (HaKI). As explained before, research roadmap has to work in line with Renstra Institusi and Rencana Induk Penelitian (RIP). Roadmap should be set by every researcher, researcher groups, and department-related to investigate the academic productivity.

In one research roadmap, it has to contain some information namely, 1) stages or events conducted on each program; 2) target outcomes; 3) executor and/or a person who is responsible; and 4) supports such as funding, tools, and etc. The visual construct of research roadmap is shown in Figure 1. 


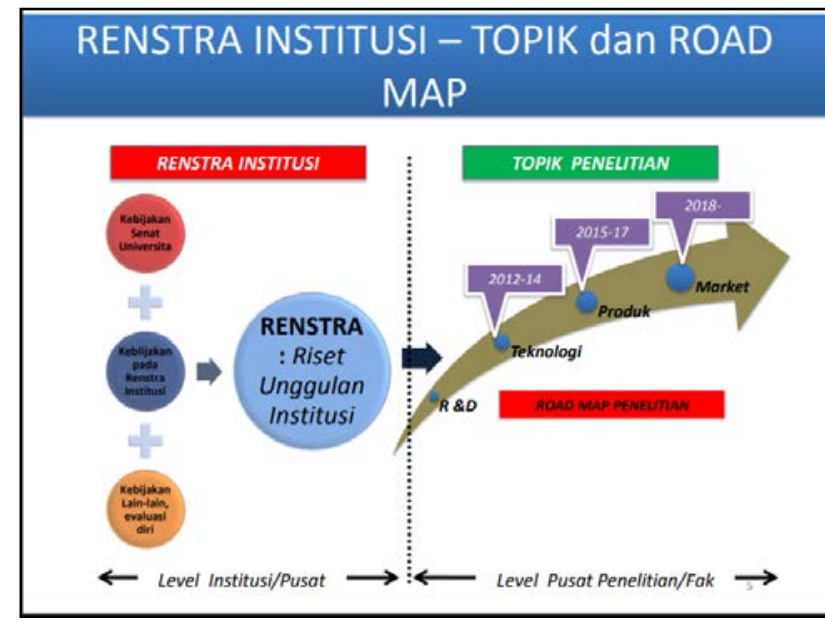

Fig. 1. The constructing of Research Roadmap

\section{METHODS}

This research uses descriptive analysis that describes the research theme and focus previously conducted by the lecturers. According to Wiersma (2000) [7], a descriptive study is a study which explores particular phenomena happening in certain time. The population of this research is all the research results or reports of the lecturers. Meanwhile, the research sampling is determined by using purposive sampling, namely adapting some techniques of sample taking based on certain criteria [8]. The specific criteria used for this research is by selecting the research reports only for the last five years in the year of 2015 to 2019 .

To conduct this research, it uses check-list documentation and questionnaire as the research instruments. Check-list is prepared for comprehending the data deeper about the research theme and focus. Meanwhile, to find out the future development of research theme, the researcher uses the second instrument that is the questionnaire. The stages of conducting this research are as follows: 1) data collection; 2) data summarizing and data classification; 3) data presentation; 4) data interpretation; and 5) data analysis.

\section{RESUlTS AND DISCUSSION}

The theme of the research conducted previously by the lecturers for the last five years is described in the following table.

TABLE I. RESEARCH THEME AND FOCUS

\begin{tabular}{|l|l|l|l|l|l|l|l|}
\hline \multirow{2}{*}{ No. } & \multicolumn{1}{|c|}{ Theme } & \multicolumn{5}{|c|}{ Year } & \multirow{2}{*}{$\sum$} \\
\cline { 3 - 9 } & & $\mathbf{2 0 1 5}$ & $\mathbf{2 0 1 6}$ & $\mathbf{2 0 1 7}$ & $\mathbf{2 0 1 8}$ & $\mathbf{2 0 1 9}$ & \\
\hline 1 & Curriculum & & & & & & 0 \\
\hline 2 & $\begin{array}{l}\text { Teaching materials } \\
\text { and learning } \\
\text { sources }\end{array}$ & 1 & 1 & 0 & 2 & 0 & 4 \\
\hline 3 & $\begin{array}{l}\text { Teaching and } \\
\text { learning strategies }\end{array}$ & 0 & 1 & 0 & 0 & 0 & 1 \\
\hline 4 & $\begin{array}{l}\text { Leaning model } \\
\text { and approach }\end{array}$ & 3 & 0 & 0 & 0 & 0 & 3 \\
\hline 5 & Learning media & 1 & 0 & 4 & 2 & 1 & 8 \\
\hline
\end{tabular}

\begin{tabular}{|c|c|c|c|c|c|c|c|}
\hline 6 & $\begin{array}{l}\text { Learning } \\
\text { environment }\end{array}$ & 0 & 0 & 0 & 0 & 0 & 0 \\
\hline 7 & $\begin{array}{l}\text { Education } \\
\text { facilities }\end{array}$ & 0 & 0 & 0 & 0 & 0 & 0 \\
\hline 8 & $\begin{array}{l}\text { Teacher's } \\
\text { competence }\end{array}$ & 0 & 0 & 1 & 0 & 1 & 2 \\
\hline 9 & $\begin{array}{l}\text { Learner's } \\
\text { characteristics }\end{array}$ & 0 & 0 & 0 & 0 & 0 & 1 \\
\hline 10 & $\begin{array}{l}\text { Education } \\
\text { management and } \\
\text { policy }\end{array}$ & 0 & 0 & 0 & 0 & 0 & 0 \\
\hline 11 & $\begin{array}{l}\text { Evaluation and } \\
\text { assessment }\end{array}$ & 1 & 1 & 1 & 1 & 1 & 5 \\
\hline 12 & Counseling & 0 & 0 & 0 & 0 & 0 & 0 \\
\hline 13 & Character Building & 0 & 0 & 0 & 0 & 0 & 0 \\
\hline 14 & $\begin{array}{l}\text { Education } \\
\text { Technology }\end{array}$ & 0 & 0 & 0 & 0 & 0 & 0 \\
\hline 15 & $\begin{array}{l}\text { Psychology } \\
\text { Education }\end{array}$ & 0 & 0 & 0 & 0 & 0 & 0 \\
\hline 16 & Online learning & 0 & 0 & 0 & 0 & 0 & 0 \\
\hline 17 & $\begin{array}{l}\text { Blended or Hybrid } \\
\text { learning }\end{array}$ & 0 & 0 & 0 & 0 & 0 & 0 \\
\hline 18 & Others & 1 & 1 & & 1 & 1 & 4 \\
\hline$\Sigma$ & & 6 & 5 & 5 & 6 & 6 & 28 \\
\hline
\end{tabular}

From the questionnaire that has been distributed, it has the results as follows: 1) the participation of the lecturers to conduct a research is high $(72 \%) ; 2$ ) the motivation of the lecturers to do a research is quite high (86\%); and 3) the research theme and focus is enough (72\%) to accommodate the knowledge field of the lecturers.

The results of the research are described as follows. First, for the last five years, there have been 28 research conducted. Based on the research rank, research theme, and research focus, the most-researched topic is about "Teaching Media" with 8 research out of 28 (29\%). Meanwhile, the less-researched topic is about "Teaching and Learning Strategies" and "Learner's Characteristics" with only one research each (1\%). There are also some themes and focuses that have not been researched before such as "Curriculum," "Learning Environment," "Education Facilities," "Education Management and Policy," "Counseling," "Character Building," "Education Technology," "Psychology Education," "Online Learning," and "Blended or Hybrid Learning." For the category "Others” is referred to the categories which have not been mentioned before in the first up to the eighteenth category, for example, a research concerning culture analysis or linguistics. Second, the future development of research theme can be associated with the current phenomena in the education field, namely Information and Communication Technologies (ICT). The categories above that are included as ICT-related are "Online Learning" and "Hybrid or Blended Learning." It can also be in a form of creativity in creating or developing learning products, community service, Research and Development (R\&D), exploration research, experimental research, and others. To view it clearly, it is necessary to create a research roadmap to find out the development of the research related to the lecturers' field. A good research roadmap will be able to reflect on the previous, on-going, and future research [9]. Those research will create predictable products that can solve problems in the society. 


\section{CONCLUSION}

It can be concluded from the discussions above that 1) there have been 28 research conducted for the last five years with the average of 6 research per year. The total of research each year can still be developed, whether it is granted or not. The category "Teaching Media” becomes the most-researched topic and can be expanded by experimenting and doing massive production as the potential products of the department which can be useful for the society. Furthermore, the lecturers also need to create a research roadmap to investigate their desired field for the future research; and 2) the future development of research theme can be associated with the current phenomena in the education field, namely Information and Communication Technologies (ICT). The categories above that are included as ICT-related are "Online Learning" and "Hybrid or Blended Learning.” It can also be in a form of creativity in creating or developing learning products, community service, Research and Development (R\&D), exploration research, experimental research, and others. Therefore, it is suggested for the department and the lecturers to start creating research roadmap and consistently conduct a research related to their field so that there will be more experts in a particular field and potential research of one certain institution and society.

\section{REFERENCES}

[1] Retrieved from http://sumberdaya.ristekdikti.go.id/wpcontent/uploads/2016/02/uu-nomor-12-tahun-2012-ttg-pendidikantinggi.pdf

[2] Rencana Induk Penelitian LPPM UNESA 2016-2020. Surabaya: LPPM.

[3] L.R. Gay, Educational Research. Colombus Ohio: Charles E. Merril Publishing Co., 1981.

[4] G.S. Sevilla, Pengantar Metodologi Penelitian. Jakarta: Universitas Indonesia Press, 1993

[5] Tuckman, and W. Bruce, Conducting Educational Research. New York: Harcourt College Publishers, 1972.

[6] T. Usman, Pengembangan Tema Penelitian Dosen Jurusan Pendidikan Teknik Otomotif Fakultas Teknik Universitas Negeri Yogyakarta, Retrieved from http://sumberdaya.ristekdikti.go.id/wpcontent/uploads/2016/02/uu-nomor-12-tahun-2012-ttg-pendidikantinggi.pdf. Laporan Penelitian UNY, 2014

[7] E.W. Wiersma, Research Methods in Education: An Introduction. Pearson: The University of Toledo Press, 2000.

[8] Sugiyono, Metode Penelitian Pendidikan-Pendekatan Kuantitatif, Kualitatif, dan R\&D. Bandung: Alfabeta, 2015.

[9] W.W.W. Brata, "Analisis Skripsi Guna Membangun Roadmap Penelitian Prodi Pendidikan Biologi,” Jurnal Pelita Pendidikan, vol. 3 , no. 4, 2015, pp. 228-238. 